\title{
Fibrinogen and D-dimer variances and anticoagulation recommendations in Covid-19: current literature review
}

(D) Mert ilker Hayıroğlu

(iD) Tufan Çınar ${ }^{2}$

Ahmet ilker Tekkeşin ${ }^{1}$

1. Department of Cardiology, Dr. Siyami Ersek Thoracic and Cardiovascular Surgery Training and Research Hospital, Istanbul, Turkey 2. Department of Cardiology, Haydarpasa Sultan Abdulhamid Han Training and Research Hospital, Istanbul, Turkey

\section{SUMMARY}

INTRODUCTION: Severe acute respiratory syndrome coronavirus 2 (SARS-CoV-2) is a newly described virus responsible for the outbreak of the coronavirus disease 2019 (Covid-19), named by the World Health Organization (WHO) in February/2020. Patients with Covid-19 have an incidence of acute respiratory distress syndrome (ARDS) of 15.9-29\% and sepsis is observed in all deceased patients. Moreover, disseminated intravascular coagulation (DIC) is one of the major underlying causes of death among these patients. In patients with $D I C$, there is a decrease in fibrinogen and an increase in D-dimer levels. Some studies have shown that fibrinogen and one of its end products, D-dimer, might have a predictive value for mortality in patients with non-Covid sepsis secondary to complications of DIC. Therefore, anticoagulation, considering its mortality benefits in cases of non-Covid sepsis, may also have an important role in the treatment of Covid-19.

METHODS: We reviewed the literature of all studies published by April 2020 on patients infected with Covid-19. Our review was limited to $D$-dimer and fibrinogen changes and anticoagulation recommendations.

RESULTS: Anticoagulation therapy can be started following the DIC diagnosis in Covid-19 patients despite the bleeding risks. In addition, the current evidence suggests a routine use of anticoagulation, particularly in patients with higher D-dimer levels $(>3.0 \mu \mathrm{g} / \mathrm{mL}$ ).

CONCLUSION: Covid-19 is a systemic, hypercoagulable disease requiring more studies concerning treatment. Aanticoagulation is still an issue to be studied, but D-dimer rise and disease severity are the indicative factors to start treatment as soon as possible.

KEYWORDS: Coronavirus Infections. Anticoagulants. Disseminated intravascular coagulation. Fibrin fibrinogen degradation products. Blood Coagulation.

\section{INTRODUCTION}

An outbreak of a newly described virus, severe acute respiratory syndrome coronavirus 2 (SARSCoV-2), has appeared worldwide with a frequent occurrence of pneumonia and its local or/and systemic complications. The virus has been named SARS-CoV-2 in China, following its first isolation from patients with pneumonia ${ }^{1}$. The disease has been later referred to as coronavirus disease 2019 (Covid-19) by the World Health Organization (WHO) in February/2020². The severity of Covid-19 increases due to the development

DATE OF SUBMISSION: 11-May-2020

DATE OF ACCEPTANCE: 23-May-2020

CORRESPONDING AUTHOR: Tufan Çınar

Department of Cardiology, Haydarpasa Sultan Abdulhamid Han Training and Research Hospital, Istanbul, Turkey

Tel: +90 (216) 542-2010 - Fax: +90 (216) 542-2020

E-mail:drtufancinar@gmail.com 
of acute respiratory distress syndrome (ARDS) and sepsis if not limited to pneumonia. Patients with Covid-19 have an incidence of ARDS of 15.9-29\%, in addition to ARDS, sepsis is observed in all deceased patients $^{3-5}$. Moreover, disseminated intravascular coagulation (DIC) is one of the major underlying causes of death in these patients. Consumption coagulopathy, which should be obviated in order to decrease mortality, arises in DIC with a decrease in fibrinogen and an increase in D-dimer levels. In fact, fibrinogen and one of its end products, D-dimer, have also been reported to have predictive value regarding the mortality of patients with non-Covid sepsis secondary to complications of $\mathrm{DIC}^{6,7}$. Therefore, anticoagulation, considering its mortality benefits in non-Covid sepsis, may also have an important role in the treatment of Covid-198.

In the current treatment strategy, patients with Covid-19 receive hydroxychloroquine and/or azithromycin as a first-line therapy ${ }^{9}$. Favipiravir, remdesivir, and lopinavir/ritonavir are the second line available after the failure of first-line therapy, but they can also be used as a first-line agent ${ }^{10}$. Despite limited data concerning drug therapies against Covid-19, biologic agents (tocilizumab, anakinra, etc.), Jak inhibitors, and corticosteroids are also available options if hemophagocytic lymphohistiocytosis occurs due to cytokine storm ${ }^{11}$. Furthermore, there is limited data and no consensus in terms of the management of patients who can take advantage of anticoagulant treatment throughout their disease course. Thus, our review article aims not only to summarize and analyze existing literature reporting on fibrinogen and D-dimer in patients infected with Covid-19 but also to discuss the role of anticoagulation strategies in Covid19 patients as a complement to standard therapies.

\section{METHODS}

A review of the literature has been implemented on the subject of anticoagulation treatment in patients infected with Covid-19. We have included the Pubmed, Embase, and Cochrane databases. They were searched on April 2020 using the following search inputs: 'covid-19, coagulation' (21 outputs), 'covid-19, coagulant' (5 outputs), 'covid-19, thrombus (17 outputs)' and the word 'coronavirus' was used instead of covid-19 in all inputs. If eligible manuscripts featured coagulation abnormalities and potential anticoagulation regimens in the treatment of Covid-19 patients, they were included in our review. Any further articles were obtained after the examination of the references from the relevant articles. Our review is limited to D-dimer and fibrinogen changes and anticoagulation recommendations, thus we did not include articles on the use of anti-platelets or anti-agregants in Covid19 patients.

\section{Fibrinogen and D-dimer}

Fibrinogen, which is known as one of the acute phase proteins, is synthesized in high quantity by the liver in response to IL-1 and IL-6 derived stimulation, as well as is involved in fibrin formation as the last step of a triggered coagulation activity ${ }^{12}$. The value of fibrinogen has already been demonstrated it has been chosen as one of the scoring parameters in DIC diagnosis according to The International Society for Thrombosis and Haemostasis (ISTH) ${ }^{12}$. Hence, fibrinogen has intrinsically appeared as the subject of investigation in the Covid-19 pandemic era due to the close relationship between Covid-19 and DIC. The dynamic changes in fibrinogen levels are remarkable and need to be addressed in Covid-19 patients. Table 1 summarizes all the investigations applied in Covid-19 patients concerning fibrinogen and D-dimer. Han et al. ${ }^{13}$ have investigated the changes in blood coagulation of patients infected with Covid-19 by comparing them with healthy controls. It is obvious that the level of fibrinogen and its degradation products are not only higher in Covid-19 patients compared to healthy controls (5.02 vs. $2.90 \mathrm{~g} / \mathrm{L}, \mathrm{p}<0.001$ ) but also higher in critical Covid-19 patients compared to mild or moderate cases (5.59 vs. $5.10 \mathrm{~g} / \mathrm{L}, \mathrm{p}<0.01)^{13}$. On the other hand, fibrinogen is reported to be non-significant between surviving and non-surviving Covid19 patients in a different cohort $(5.16$ vs. $4.51 \mathrm{~g} / \mathrm{L}, \mathrm{p}=$ $0.149)^{14}$. Thus, it is not difficult to interpret this as an admission that fibrinogen is expected to be higher than normal levels in hospitalized patients; however, it might not have a predictive value for mortality in Covid-19 patients. Fibrinogen should be evaluated together with D-dimer levels in order to have more proper prognostic assumptions since its gradual decrease together with higher D-dimer levels have a role in diagnosing DIC status as early as possible in sepsis.

D-dimer is the soluble plasmin-mediated degradation product of fibrin, which is produced after activation of coagulation and fibrinolysis ${ }^{25}$ (Figure 1). D-dimer, which is also determined as one of the 
TABLE 1. STUDIES PRESENT THE COAGULATION PARAMETERS IN PATIENTS WITH COVID-19 INFECTION

\begin{tabular}{|c|c|c|c|c|c|c|}
\hline & $\begin{array}{l}\text { Study } \\
\text { design }\end{array}$ & $\begin{array}{l}\text { Study } \\
\text { population }\end{array}$ & $\begin{array}{l}\text { Coagulation } \\
\text { parameters }\end{array}$ & Results & $\begin{array}{l}P \\
\text { value }\end{array}$ & $\begin{array}{l}\text { Supplementary } \\
\text { information }\end{array}$ \\
\hline Zhou et al. ${ }^{2}$ & $\begin{array}{l}\text { Retro- } \\
\text { spective }\end{array}$ & $\begin{array}{l}\text { Covid-19 patients survivor } \\
\text { ( } n=137) \text { vs. Covid-19 patients } \\
\text { non-survivor }(n=54)\end{array}$ & $\begin{array}{l}\text { D-dimer, } \mu g / \\
\mathrm{mL}\end{array}$ & 0.6 vs. 5.2 & $<0.001$ & $\begin{array}{l}\text { *Value of D-dimer above } 1 \\
\text { was associated with 18-fold higher } \\
\text { mortality [OR=18.42, 95\% Cl: } 2.64-128.55 \text {, } \\
p=0.0033]\end{array}$ \\
\hline Han et al. ${ }^{13}$ & $\begin{array}{l}\text { Retro- } \\
\text { spective }\end{array}$ & $\begin{array}{l}\text { Control }(n=40) \text { vs. Covid-19 } \\
\text { patients }(n=94)\end{array}$ & $\begin{array}{l}\text { D-dimer, } \\
\text { mg/dl } \\
\text { Fibrinogen, } \\
\text { g/L }\end{array}$ & $\begin{array}{l}0.26 \text { vs. } \\
10.36 \\
2.90 \text { vs. } 5.02\end{array}$ & $\begin{array}{l}<0.001 \\
<0.001\end{array}$ & $\begin{array}{l}\text { *Significantly higher D-dimer and fibrin- } \\
\text { ogen levels were present in patients with } \\
\text { Covid-19 diseases. }\end{array}$ \\
\hline Tang et al. ${ }^{\mathbf{1 4}}$ & $\begin{array}{l}\text { Retro- } \\
\text { spective }\end{array}$ & $\begin{array}{l}\text { Covid-19 surviving pa- } \\
\text { tients ( } n=162 \text { ) vs. Covid-19 } \\
\text { non-surviving patients ( } n= \\
\text { 21) }\end{array}$ & $\begin{array}{l}\text { D-dimer, } \\
\text { mg/dl } \\
\text { Fibrinogen, } \\
\text { g/L }\end{array}$ & $\begin{array}{l}0.61 \text { vs. } 2.12 \\
4.51 \text { vs. } 5.16\end{array}$ & $\begin{array}{l}<0.001 \\
0.149\end{array}$ & $\begin{array}{l}{ }^{*} \text { D-dimer level above } 3 \text { and fibrinogen } \\
\text { level below } 1 \text { were present in } 85.7 \% \text { and } \\
28.6 \% \text {, respectively, in Covid- } 19 \text { patients } \\
\text { who developed DIC. }\end{array}$ \\
\hline Cui et al. ${ }^{15}$ & $\begin{array}{l}\text { Retro- } \\
\text { spective }\end{array}$ & $\begin{array}{l}\text { Covid-19 non-VTE patients } \\
\text { ( } n=61) \text { vs. Covid-19 VTE } \\
\text { patients }(n=20)\end{array}$ & $\begin{array}{l}\text { D-dimer, } \mu g / \\
\mathrm{mL}\end{array}$ & 0.8 vs. 5.2 & $<0.001$ & $\begin{array}{l}\text { * }>1.5 \mu \mathrm{g} / \mathrm{mL} \text { as the } \mathrm{D} \text {-dimer cut-off value } \\
\text { to predicting VTE }\end{array}$ \\
\hline Liu et al. ${ }^{16}$ & $\begin{array}{l}\text { Retro- } \\
\text { spective }\end{array}$ & $\begin{array}{l}\text { Mild Covid-19 patients }(n= \\
26) \text { vs. severe Covid-19 } \\
\text { patients }(n=4)\end{array}$ & $\begin{array}{l}\text { D-dimer, } \\
\mathrm{mg} / \mathrm{dl}\end{array}$ & 0.26 vs. 1.54 & $<0.001$ & $\begin{array}{l}\text { *Severe Covid-19 patient had higher } \\
\text { D-dimer values compared to mild cases. }\end{array}$ \\
\hline Qui et al. ${ }^{17}$ & $\begin{array}{l}\text { Retro- } \\
\text { spective }\end{array}$ & $\begin{array}{l}\text { Mild Covid-19 pediatric } \\
\text { patients }(n=17) \text { vs. moderate } \\
\text { Covid-19 pediatric patients } \\
(n=19)\end{array}$ & $\begin{array}{l}\text { D-dimer, } \mu g / \\
\mathrm{mL}\end{array}$ & 0.21 vs. 0.36 & 0.028 & $\begin{array}{l}{ }^{*} \text { Moderate Covid-19 pediatric patients } \\
\text { had increased D-dimer levels compared } \\
\text { to those with mild Covid-19 disease }\end{array}$ \\
\hline $\begin{array}{l}\text { Chen et } \\
\text { al. }^{\mathbf{1 8}}\end{array}$ & $\begin{array}{l}\text { Retro- } \\
\text { spective }\end{array}$ & $\begin{array}{l}\text { Moderate Covid-19 patients } \\
(n=10) \text { vs. severe Covid-19 } \\
\text { patients }(n=11)\end{array}$ & $\begin{array}{l}\text { D-dimer, } \mu g / \\
m L\end{array}$ & 0.3 vs. 2.6 & 0.029 & $\begin{array}{l}\text { *Severe Covid-19 patients had increased } \\
\text { D-dimer levels compared to those with } \\
\text { moderate Covid-19 disease }\end{array}$ \\
\hline $\begin{array}{l}\text { Zhang et } \\
\text { al. }{ }^{19}\end{array}$ & $\begin{array}{l}\text { Retro- } \\
\text { spective }\end{array}$ & $\begin{array}{l}\text { Non-severe Covid-19 } \\
\text { patients }(n=82) \text { vs. severe } \\
\text { Covid-19 patients ( } n=56)\end{array}$ & $\begin{array}{l}\text { D-dimer, } \\
\mathrm{mg} / \mathrm{dl}\end{array}$ & 0.2 vs. 0.4 & $<0.001$ & $\begin{array}{l}{ }^{*} \text { More elevated D-dimer levels were } \\
\text { found in severe Covid- } 19 \text { patients com- } \\
\text { pared to non-severe Covid-19 patients }\end{array}$ \\
\hline $\begin{array}{l}\text { Zhou et } \\
\text { al. }{ }^{20}\end{array}$ & $\begin{array}{l}\text { Retro- } \\
\text { spective }\end{array}$ & $\begin{array}{l}\text { Covid-19 patients without } \\
\text { aggravation }(n=12) \text { vs. } \\
\text { Covid- } 19 \text { patients with aggra- } \\
\text { vation }(n=5)\end{array}$ & $\begin{array}{l}\text { D-dimer, } \\
\text { mg/dl }\end{array}$ & 0.29 vs. 0.28 & 0.922 & $\begin{array}{l}{ }^{*} \text { D-dimer was not a factor associated } \\
\text { with disease progression in patients } \\
\text { infected with Covid-19 }\end{array}$ \\
\hline Wu et al. ${ }^{21}$ & $\begin{array}{l}\text { Retro- } \\
\text { spective }\end{array}$ & $\begin{array}{l}\text { Covid-19 patients without } \\
\text { ARDS }(n=117) \text { vs. Covid-19 } \\
\text { patients with ARDS }(n=84)\end{array}$ & $\begin{array}{l}\text { D-dimer, } \mu \mathrm{g} / \\
\mathrm{mL}\end{array}$ & 0.52 vs. 1.16 & 0.001 & $\begin{array}{l}{ }^{*} \mathrm{D} \text {-dimer was associated with a higher } \\
\text { risk of the development of ARDS [OR= } \\
1.03,95 \% \mathrm{Cl}: 1.01-1.04 ; \mathrm{p}<0.001]\end{array}$ \\
\hline Wu et al. ${ }^{21}$ & $\begin{array}{l}\text { Retro- } \\
\text { spective }\end{array}$ & $\begin{array}{l}\text { Covid-19 patients with ARDS } \\
\text { (alive) ( } n=40) \text { vs. Covid-19 } \\
\text { patients with ARDS (died) } \\
(n=44)\end{array}$ & $\begin{array}{l}\text { D-dimer, } \mu \mathrm{g} / \\
\mathrm{mL}\end{array}$ & 0.49 vs. 3.95 & 0.001 & $\begin{array}{l}{ }^{*} \text { D-dimer was associated with a higher } \\
\text { risk of death in Covid-19 patients with } \\
\text { ARDS }[O R=1.02,95 \% \mathrm{Cl} \text { : } 1.01-1.04 ; p= \\
0.002] \text {. }\end{array}$ \\
\hline Yin et al. ${ }^{22}$ & $\begin{array}{l}\text { Retro- } \\
\text { spective }\end{array}$ & $\begin{array}{l}\text { Covid-19 patients with severe } \\
\text { pneumonia }(n=449) \text { vs. non- } \\
\text { Covid-19 patients with severe } \\
\text { pneumonia }(n=104)\end{array}$ & $\begin{array}{l}\text { D-dimer, } \mu g / \\
m L\end{array}$ & 1.94 vs. 2.52 & 0.140 & $\begin{array}{l}{ }^{*} \text { When D-dimer exceeded } 3.0 \mu \mathrm{g} / \mathrm{mL} \\
\text { (six-fold the upper limit of normal), sig- } \\
\text { nificantly lower mortality in heparin users } \\
\text { than nonusers was found in Covid-19 } \\
\text { patients ( } 32.8 \% \text { vs. } 52.4 \%, p=0.017 \text { ). }\end{array}$ \\
\hline $\begin{array}{l}\text { Tang et } \\
\text { al. }^{23}\end{array}$ & $\begin{array}{l}\text { Retro- } \\
\text { spective }\end{array}$ & $\begin{array}{l}\text { Covid-19 surviving pa- } \\
\text { tients ( } n=315 \text { ) vs. Covid-19 } \\
\text { non-surviving patients ( } n= \\
\text { 134) }\end{array}$ & $\begin{array}{l}\text { D-dimer, } \\
\text { mg/dl }\end{array}$ & 1.47 vs. 4.70 & $<0.001$ & $\begin{array}{l}{ }^{*} \mathrm{D} \text {-dimer was positively correlated with } \\
28 \text {-day mortality in multivariate analysis } \\
{[\mathrm{OR}=1.058,95 \% \mathrm{Cl}: 1.028-1.090 ; \mathrm{p}<} \\
0.001] \text {. } \\
{ }^{*} \text { The } 28 \text {-day mortality of heparin users } \\
\text { was lower than that of nonusers in } \\
\text { patients with } \mathrm{D} \text {-dimer }>6 \text { fold the } \\
\text { upper limit of normal ( } 32.8 \% \text { vs. } 52.4 \% \text {, } \\
p=0.017 \text { ). }\end{array}$ \\
\hline $\begin{array}{l}\text { Zhang et } \\
\text { al. }^{24}\end{array}$ & $\begin{array}{l}\text { Retro- } \\
\text { spective }\end{array}$ & $\begin{array}{l}\text { Covid-19 surviving patients } \\
\text { ( } n=89 \text { ) vs. Covid- } 19 \text { non-sur- } \\
\text { viving patients }(n=6)\end{array}$ & $\begin{array}{l}\text { D-dimer, } \\
\text { mg/L }\end{array}$ & $\begin{array}{l}\text { The D-dimer } \\
\text { level was } \\
\text { present as } \\
\leq 1 \text { and }>1 \\
\text { respectively }\end{array}$ & 0.001 & $\begin{array}{l}{ }^{*} \text { For the }>1 \mathrm{mg} / \mathrm{L} \text { group, } 81.2 \% \text { of the } \\
\text { patients were severe Covid-19 cases, } \\
\text { and } 71.9 \% \text { of the patients reached the } \\
\text { composite endpoints including intensive } \\
\text { care unit admission or death. } \\
{ }^{*} \text { Higher D-dimer level was strongly re- } \\
\text { lated to severe Covid-19 pneumonia and } \\
\text { composite endpoints, including intensive } \\
\text { care unit admission or death ( } p<0.001) \text {. }\end{array}$ \\
\hline
\end{tabular}

Abbreviations: VTE - venous thromboembolism; ARDS - acute respiratory distress . syndrome; DIC - disseminated intravascular coagulation; OR - odds ratio; CI - confidence interval. 


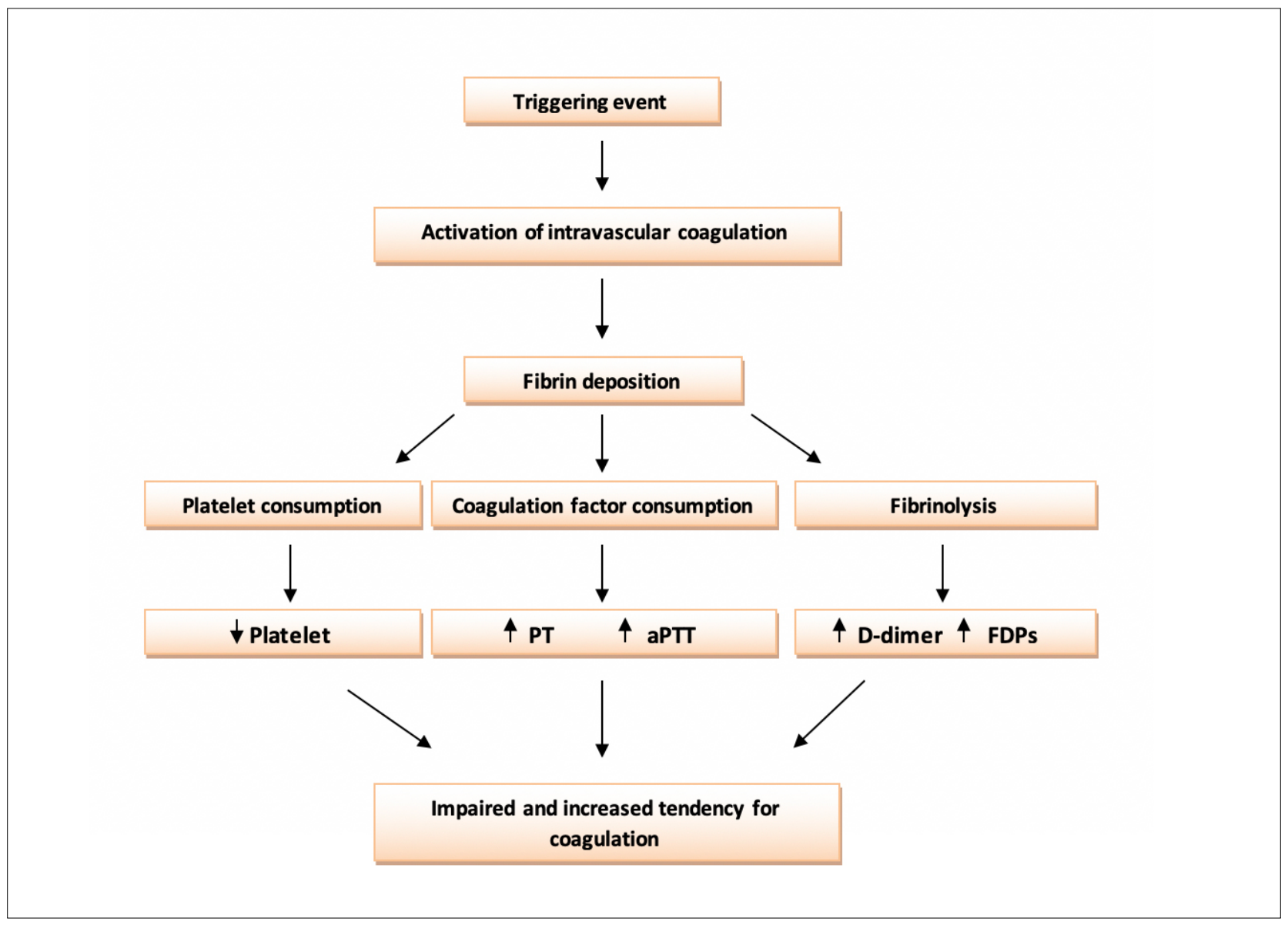

diagnostic criteria of DIC, is usually used in order to diagnose or exclude thrombotic events such as deep venous thrombosis or pulmonary embolism ${ }^{15}$. Venous thromboembolism (VTE) is a frequent complication of critical illnesses, particularly in patients treated in intensive care units (ICU). The frequency of VTE has been reported to be $13 \%$ in patients of a respiratory intensive care unit ${ }^{26}$. On the other hand, the incidence of VTE has been $25 \%$ in patients with severe Covid-19 in the ICU, which also represents a hypercoagulable process in Covid-19 patients ${ }^{15}$. The D-dimer levels are also higher in patients with DVT compared to non-DVT. (5.2 vs. $0.8 \mu \mathrm{g} / \mathrm{mL}, \mathrm{p}<0.001$ ) D-dimer within normal limits has been already known to have a higher sensitivity but lower specificity for acute thrombosis. Since we experience higher D-dimer levels in most Covid-19 patients, it is also important to determine a specific level to predict thrombosis. Cui et al. ${ }^{15}$ have proposed $3.0 \mathrm{\mu g} / \mathrm{mL}$ as the cut off value to predict VTE with a sensitivity of $76.9 \%$, a specificity of $94.9 \%$, and a negative predictive value of $92.5 \%$.
The serum level of D-dimer has been also reported to be higher if the severity of the disease increases ${ }^{16-19}$. Despite expectancy of higher D-dimer levels in severe Covid-19 patients, it is important to observe statistically significant D-dimer levels in moderate Covid19 pediatric patients compared to milder ones (0.36 vs. $0.21 \mu \mathrm{g} / \mathrm{mL}, \mathrm{p}<0.028)^{17}$. However, in a different cohort with fewer patients, there has been no difference in terms of D-dimer level in Covid-19 patients without or with aggravation $(0.29 \mathrm{vs} .0 .28 \mathrm{mg} / \mathrm{dL}, \mathrm{p}=$ $0.922)^{20}$. Nevertheless, if we consider D-dimer as a prognostic marker, it has been significantly higher in patients with ARDS and independently associated with a higher risk of ARDS development (1.16 vs. $0.52 \mu \mathrm{g} / \mathrm{mL}, \mathrm{p}<0.001 ; \mathrm{OR}=1.03,95 \%: 1.01-1.04 ; \mathrm{p}<$ $0.001)^{21}$. Noteworthy, D-dimer has been proved to be higher in non-surviving patients when compared to

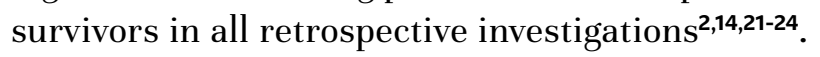
Several of these investigations have emphasized D-dimer exceeding $3.0 \mu \mathrm{g} / \mathrm{mL}$ (six-fold the upper limit of normal) as a cut-off value for diagnosing $85.7 \%$ of the 
patients with DIC and guiding the anticoagulation treatment in order to decrease mortality secondary to Covid-19 $9^{14,22}$. As a result, D-dimer has shown a promising value to direct anticoagulation strategies in the treatment of Covid-19.

\section{Anticoagulation}

Covid-19 causes clinical complications of multiple organs; however, the main complication occurs in the pulmonary system due to the high expression of SARS-CoV-2 receptor ACE2 and TMPRSS2 in the bronchial cells ${ }^{27}$. The destruction in the lungs has been presented in a histopathological study showing alveolar septal vascular congestion, eosinophil and lymphocyte infiltration, alveolar exudation, and thrombosis in pulmonary circulation ${ }^{28}$. The main underlying mechanism, which is accused of higher coagulation tendency during Covid-19, is the over-activation of the immune system causing complement release syndrome. Elevated cytokines such as IL-6 stand as the key modulator in cellular immune response and are the trigger factor for coagulation disorders ${ }^{29}$. Therefore, anticoagulation treatment should be investigated in Covid-19 since a hypercoagulable state has been demonstrated in both cellular and organ levels.

Early anticoagulation has been suggested in order to reduce thrombosis and microthrombus burden by Li et al..$^{30}$, a professor who worked in frontline care in Wuhan. However, his suggestions are based upon his individual experience in Covid-19 patients. In fact, there are controversial articles and some comments about anticoagulation treatment in Covid-19. First of all, complement activation is said to cause a systemic thrombotic tendency, thus complementary inhibition therapy should be the first target therapy to prevent thrombotic microangiopathy, according to Campbell and Kahwash ${ }^{31}$. Moreover, similarities of lung findings have been exhibited between high altitude pulmonary edema (HAPE) and Covid-19 in a recent article, which suggested HAPE as an analogous disease to Covid-19. For this reason, acetazolamide, nifedipine, and phosphodiesterase inhibitors have been proposed to be prescribed in Covid-19 since elevated fibrinogen level has been considered as an epiphenomenon of edema rather than coagulation activation $^{32}$. Conversely, a retrospective study has already tested the efficacy of anticoagulant therapy in Covid-19 and resulted in a reduction in mortality when D-dimer exceeded 3.0 $\mathrm{\mu g} / \mathrm{mL}$ (32.8\% vs. $52.4 \%$, $\mathrm{p}=0.017)^{23}$. The results may be due to the hypercoagulable state of the disease, or the anti-inflammatory effect of anticoagulation, or the combination of these two reasons ${ }^{33}$. An interesting study on tissue plasminogen activator (tPA) use for Covid19 induced ARDS has shown amelioration in the $\mathrm{PaO} 2 / \mathrm{FiO} 2$ ratio, which may be considered a clue for the necessity of anticoagulation prior to ARDS onset34. Anticoagulation therapy has also been beneficial in non-Covid 19 induced DIC, thus it should be immediately started following the DIC diagnosis in Covid-19 patients despite the bleeding risks ${ }^{35}$. In addition, the current evidence suggests the routine use of anticoagulation, particularly in patients with higher D-dimer levels $(>3.0 \mu \mathrm{g} / \mathrm{mL})$. However, in light of existing data, the early administration of anticoagulation should be addressed with further investigations in Covid-19 patients without DIC. As a result, thromboprophylaxis in Covid-19 has been already suggested by position papers in several coun$\operatorname{tries}^{36,37}$. However, routine anticoagulation for Covid19 patients should be tested by more studies since current evidence directs clinicians to the routine use of anticoagulation merely in severe Covid-19 patients.

\section{CONCLUSION}

Covid-19 is a systemic, hypercoagulable disease requiring more studies regarding treatment. Routine thromboprophylaxis should be performed in all patients because of the nature of the disease and immobilization during treatment and isolation are required. Anticoagulation is still an issue to be studied, but increased D-dimer and disease severity are the indicative factors to start the treatment as soon as possible.

\section{Conflict of interest}

All authors declare they do not have any conflicts of interest.

\section{Author contribution}

Conception: M.İ.H., T.Ç., Design: M.İ.H., T.Ç.; Supervision: A.İ.T. Fundings: A.İ.T ; Materials: M.İ.H., T.Ç.; Data Collection: M.İ.H., T.Ç. Analysis: M.İ.H.; Literature Review: T.Ç., A.İ.T. ; Writer: M.I..H. Critical Review: A.I.T. 


\section{RESUMO}

INTRODUÇÃO: O coronavírus da síndrome respiratória aguda grave 2 (SARS-CoV-2) é o vírus responsável pelo surto recentemente batizado de doença pelo coronavirus 2019 (Covid-19) pela Organização Mundial de Saúde (OMS) em fevereiro/2020. Os doentes com Covid-19 têm uma incidência de síndrome de dificuldade respiratória aguda (SDRA) de 15,9-29\% e sepse é observada em todos os pacientes que vêm a óbito. Além disso, a coagulação intravascular disseminada (DIC) é uma das principais causas subjacentes de morte entre esses pacientes. Em pacientes com DIC, ocorre com uma diminuição do fibrinogênio e um aumento dos níveis de dímero D. Alguns estudos mostraram que o fibrinogênio e um dos seus produtos finais, o dímero $D$, podem ter um valor preditivo para a mortalidade em pacientes com sepse não relacionada à Covid-19 decorrente de complicações da DIC. Portanto, a anticoagulação, considerando seus benefícios quanto à mortalidade na sepse não relacionada à Covid-19, pode também ter um papel importante no tratamento da Covid-19.

MÉTODOs: Realizamos uma revisão de todos os estudos publicados até abril de 2020 sobre pacientes infectados com Covid-19. A nossa revisão limitou-se a alterações no dímero $D$, nos fibrinogênios e recomendações de anticoagulantes.

RESULTADOS: A terapêutica anticoagulante pode ser iniciada após o diagnóstico de DIC em pacientes com Covid-19 apesar dos riscos de hemorragia. Além disso, a evidência atual sugere o uso rotineiro da anticoagulação, principalmente em pacientes com níveis mais elevados de dímero $D(>3,0 \mu \mathrm{g} / \mathrm{mL})$.

CONCLUSÃO: A Covid-19 é uma doença sistêmica e hipercoagulável que requer mais estudos em relação ao tratamento. A anticoagulação ainda é uma questão a ser estudada, mas o aumento de dímeros $D$ e a gravidade da doença são os fatores indicativos para o início do tratamento o mais rápido possível.

PALAVRAS-CHAVE: Infecções por Coronavirus. Anticoagulantes. Coagulação intravascular disseminada. Produtos de Degradação da Fibrina e do Fibrinogênio. Coagulação Sanguínea.

\section{REFERENCES}

1. Phelan AL, Katz R, Gostin LO. The novel coronavirus originating in Wuhan, China: challenges for global health governance. JAMA. 2020. doi: 10.1001/ jama.2020.1097

2. Zhou F, Yu T, Du R, Fan G, Liu Y, Liu Z, et al. Clinical course and risk factors for mortality of adult inpatients with COVID-19 in Wuhan, China: a retrospective cohort study. Lancet. 2020;395(10229):1054-62.

3. Wang D, Hu B, Hu C, Zhu F, Liu X, Zhang J, et al. Clinical characteristics of 138 hospitalized patients with 2019 novel coronavirus-infected pneumonia in Wuhan, China. JAMA. 2020;323(11):1061-9.

4. Huang $C$, Wang $Y$, Li X, Ren L, Zhao I, Hu Y, et al. Clinical features of patients infected with 2019 novel coronavirus in Wuhan, China. Lancet. 2020;395(10223):497-506.

5. Chen T, Wu D, Chen H, Yan W, Yang D, Chen G, et al. Clinical characteristics of 113 deceased patients with coronavirus disease 2019: retrospective study. BMJ. 2020;368: m1091.

6. Matsubara T, Yamakawa K, Umemura Y, Gando S, Ogura H, Shiraishi A, et al. Significance of plasma fibrinogen level and antithrombin activity in sepsis: a multicenter cohort study using a cubic spline model. Thromb Res. 2019;181:17-23.

7. Zhan Z, Li C. Prognostic value of d-dimer in patients with sepsis in emergency department: a prospective study. Zhongguo Wei Zhong Bing Ji jiu Yi Xue. 2012;24(3):135-9.

8. Wang C, Chi C, Guo L, Wang X, Guo L, Sun J, et al. Heparin therapy reduces 28-day mortality in adult severe sepsis patients: a systematic review and meta-analysis. Crit Care. 2014;18(5):563.

9. Cortegiani A, Ingoglia G, Ippolito M, Giarratano A, Einav S. A systematic review on the efficacy and safety of chloroquine for the treatment of COVID-19. J Crit Care. 2020;57:279-83.

10. Dong L, Hu S, Gao J. Discovering drugs to treat coronavirus disease 2019 (COVID-19). Drug Discov Ther. 2020;14(1):58-60.

11. Weaver LK, Behrens EM. Weathering the storm: improving therapeutic interventions for cytokine storm syndromes by targeting disease pathogenesis. Curr Treatm Opt Rheumatol. 2017;3(1):33-48.

12. Levi $\mathrm{M}$, Toh $\mathrm{CH}$, Thachil J, Watson HG. Guidelines for the diagnosis and management of disseminated intravascular coagulation. British Committee for Standards in Haematology. Br J Haematol. 2009;145(1):24-33.

13. Han H, Yang L, Liu R, Liu F, Wu KL, Li J, et al. Prominent changes in blood coagulation of patients with SARS-CoV-2 infection. Clin Chem Lab Med. 2020. doi: 10.1515/cclm-2020-0188.
14. Tang N, Li D, Wang X, Sun Z. Abnormal coagulation parameters are associated with poor prognosis in patients with novel coronavirus pneumonia. J Thromb Haemost. 2020;18(4):844-7.

15. Cui S, Chen S, Li X, Liu S, Wang F. Prevalence of venous thromboembolism in patients with severe novel coronavirus pneumonia. I Thromb Haemost. 2020. doi: 10.1111/jth.14830.

16. Liu M, He P, Liu HG, Wang XJ, Li FJ, Chen S, et al. Clinical characteristics of 30 medical workers infected with new coronavirus pneumonia. Zhonghua jie He He Hu Xi Za Zhi. 2020;43(3):209-14.

17. Qiu H, Wu J, Hong L, Luo Y, Song Q, Chen D, et al. Clinical and epidemiological features of 36 children with coronavirus disease 2019 (COVID19) in Zhejiang, China: an observational cohort study. Lancet Infect Dis. 2020;20(6):689-96.

18. Chen G, Wu D, Guo W, Cao Y, Huang D, Wang H, et al. Clinical and immunological features of severe and moderate coronavirus disease 2019. I Clin Invest. 2020;130(5):2620-9.

19. Zhang JJ, Dong X, Cao YY, Yuan YD, Yang YB, Yan YQ, et al. Clinical characteristics of 140 patients infected with SARS-CoV-2 in Wuhan, China. Allergy. 2020. doi: $10.1111 /$ all.14238.

20. Zhou Y, Zhang Z, Tian J, Xiong S. Risk factors associated with disease progression in a cohort of patients infected with the 2019 novel coronavirus. Ann Palliat Med. 2020;9(2):428-36

21. Wu C, Chen X, Cai Y, Xia J, Zhou X, Xu S, et al. Risk factors associated with acute respiratory distress syndrome and death in patients with coronavirus disease 2019 pneumonia in Wuhan, China. JAMA Intern Med. 2020;e200994.

22. Yin S, Huang M, Li D, Tang N. Difference of coagulation features between severe pneumonia induced by SARS-CoV2 and non-SARS-CoV2. J Thromb Thrombolysis. 2020;1-4.

23. Tang N, Bai H, Chen X, Gong J, Li D, Sun Z. Anticoagulant treatment is associated with decreased mortality in severe coronavirus disease 2019 patients with coagulopathy. J Thromb Haemost. 2020;18(5):1094-9.

24. Zhang G, Zhang J, Wang B, Zhu X, Wang Q, Qiu S. Analysis of clinical characteristics and laboratory findings of 95 cases of 2019 novel coronavirus pneumonia in Wuhan, China: a retrospective analysis. Respir Res. 2020;21(1):74.

25. Zakai NA, McClure LA, Judd SE, Kissela B, Howard G, Safford M, et al. $D$-dimer and the risk of stroke and coronary heart disease. The REasons for Geographic and Racial Differences in Stroke (REGARDS) study. Thromb Haemost. 2017;117(3):618-24. 
26 Moser KM, LeMoine IR, Nachtwey F|, Spragg RG. Deep venous thrombosis and pulmonary embolism. Frequency in a respiratory intensive care unit. JAMA. 1981;246(13):1422-4.

27 Lukassen S, Chua RL, Trefzer T, Kahn NC, Schneider MA, Muley T, et al. SARS-CoV-2 receptor ACE2 and TMPRSS2 are primarily expressed in bronchial transient secretory cells. EMBO J. 2020;39(10):e105114.

28. Yao XH, Li TY, He ZC, Ping YF, Liu HW, Yu SC, et al. A pathological report of three COVID-19 cases by minimally invasive autopsies. Zhonghua Bing Li Xue Za Zhi. 2020;49(5):411-7.

29. Tanaka T, Narazaki M, Kishimoto T. Immunotherapeutic implications of IL-6 blockade for cytokine storm. Immunotherapy. 2016;8(8):959-70.

30. Li T, Lu H, Zhang W. Clinical observation and management of COVID-19 patients. Emerg Microbes Infect. 2020;9(1):687-90.

31. Campbell CM, Kahwash R. Will complement inhibition be the new target in treating COVID-19 related systemic thrombosis? Circulation. 2020;141(22):1739-41.

32. Solaimanzadeh I. Acetazolamide, nifedipine and phosphodiesterase inhibitors: rationale for their utilization as adjunctive countermeasures in the treatment of coronavirus disease 2019 (COVID-19). Cureus. 2020;12(3):e7343.

33. Li X, Li L, Shi Y, Yu S, Ma X. Different signaling pathways involved in the anti-inflammatory effects of unfractionated heparin on lipopolysaccharide-stimulated human endothelial cells. J Inflamm (Lond). 2020;17:5.

34. Wang J, Hajizadeh N, Moore EE, Mclntyre RC, Moore PK, Veress LA, et al. Tissue plasminogen activator (tPA) treatment for COVID-19 associated acute respiratory distress syndrome (ARDS): a case series. J Thromb Haemost. 2020. doi: 10.1111/jth.14828.

35. Murao S, Yamakawa K. A systematic summary of systematic reviews on anticoagulant therapy in sepsis. J Clin Med. 2019;8(11):1869.

36. Marietta M, Ageno W, Artoni A, Candia E, Gresele P, Marchetti M, et al. COVID-19 and haemostasis: a position paper from Italian Society on Thrombosis and Haemostasis (SISET). Blood Transfus. 2020;18(3):167-9.

37. Casini A, Alberio L, Angelillo-Scherrer A, Fontana P, Gerber B, Graf L, et al. Thromboprophylaxis and laboratory monitoring for in-hospital patients with COVID-19 - a Swiss Consensus Statement by the Working Party Hemostasis. Swiss Med Wkly. 2020;150:w20247. 